\title{
Cost of Funds of Non-Bank Financial Institutions in Bangladesh: Internal Factors Analysis
}

\author{
Md. Mosharref Hossain ${ }^{1}$, Md. Mahabbat Hossain²
}

Lecturer, Bangladesh Institute of Bank Management (BIBM), Bangladesh

\begin{abstract}
Non-Bank Financial Institutions (NBFIs) are increasingly being recognized as complementary to the banking system and perform a diversified range of functions through offering various financial services to individual, corporate and institutional clients. Nevertheless, the cost of funds of NBFIs is significantly higher than the banks as banks are the prime sources of funds for them. On the other hand, the availability of funds from banks is becoming inadequate day by day due to the involvement of banks with some similar functions of NBFIs. The study intended to identify the current scenario of the cost of funds of different groups of NBFIs and to find out the causal relationship of the internal factors with the cost of funds of NBFIs. The study finds that NBFIs established before 1990 shows higher equity contribution and total asset size which shows their ability to generate funds at a low cost for the reputation and public confidence. On the other hand, due to the high equity contribution, large asset size and high EPS of the group of joint venture NBFIs compared to local NBFIs are able to raise relatively low cost funds. From the multiple regression analysis current study finds that only the variables of age and earning per share are statistically significant at $5 \%$ level. The other two factors, equity contribution and interest earning asset conform the theoretical sign although they are not statistically significant. The other variable, size of business that is measured by total asset, neither conform the expected sign nor is statistically significant.
\end{abstract}

Keywords: NBFIs, COF, Internal Factors, Bangladesh.

\section{INTRODUCTION}

$\mathrm{N}$ on-Bank Financial Institutions (NBFIs) have come to be regarded as important financial intermediaries as they playing pivotal role in broadening access to financial services, enhancing competition and diversification of the financial sector. By providing additional and alternative financial services, NBFIs have already gained considerable popularity in both developed and developing countries (Ahmed and Chowdhury 2007). The NBFI sector in Bangladesh consists of development financial institutions, leasing companies, investment companies, merchant bank, etc. At present, 31 NBFIs are operating their business across the country. They are increasingly being recognized as complementary to the banking system, capable of absorbing shocks and spreading risks at times of financial distress. Saha et al. (1999) and Chowdhury (1999) analyzed and highlighted problems and prospects of NBFIs in Bangladesh. They emphasized on the complementary role of NBFIs with BFIs in different areas like contribution in term lending with special discussion on leasing, role in capital market development, problems in availability of fund, impact of NBFIs' Deposit Mobilization on the Monetary Policy, etc. According to Goldsmith (1969), financial development in a country starts with the development of banking institutions. Now the sector has turned increasingly into rival of the banking sector in terms of firm size and also offering dynamic services in line with the traditional services.

NBFIs provide financial services that differ from those provided by banks and create a variety of financial services as well as increase competition between different financial institutions. NBFIs sector represents one of the most important segments of the financial system and plays a very important role in mobilizing and channeling resources. In the present day, this sector continuously playing an important role in financing industry, trade and commerce, housing, etc. and thereby contributing significantly to the economic development of the country. With the challenges of time, the overall growth of the leasing business achieved through diversification of products and services and aggressive marketing with special focus on the SME sector, is indicative of the industry's contribution to our national economy.

The major funding sources of NBFIs are capital, term deposits, credit facilities from banks and other financial institutions like insurance companies, call money, bonds and securitization and high net worth individuals. Among all the sources, commercial banks is one of the major sources of funds for NBFIs and also the major investors in bond/debentures issued by them. Although NBFIs have immense necessity and greater importance in the financial system of Bangladesh, they are severely suffering from some problems including the fund problem in terms of both availability and cost (Hossain \& Shahiduzzaman, 2002). NBFIs are mostly dependent on funds from the credit lines of the commercial banks at a relatively higher rate of interest. Recently banks are increasingly moving into the domain of non banks and have been increasingly taking over much of the role of the non banks as they have the advantage of lower costs of fund compared to the NBFIs. Entry of the commercial banks and development 
financing institutions into the business of NBFIs, particularly in term lending, leasing \& hire purchase, capital market operations, provides a further twist to the tale. For these consequences, NBFIs are increasingly finding it difficult to source funds from traditional banking sources. In order to overcome the funding problems, NBFIs are moving for a greater share of their funds from the public and institutions. Some of the larger ones moved to collect deposits from the high net worth public with dedicated personnel and are managing about $90 \%$ of their fund requirement by this mode (Khan, 2010). A few of the institutions moved into the bond market for their funding needs. NBFIs are trying to depend on the capital market as it become increasingly apparent that they could no longer source their funding requirements from the banking sector. As many as 21 non banks are currently listed with the Stock exchanges and the remaining is likely to complete their listing immediately. According to the Report on Trend and Progress of Banking in India 2010-11, Commercial paper emerged as the single most important channel accounting for more than 70 per cent of the total resources mobilized by FIs from the money market in 2010-11 (Reserve Bank of India (2011). If NBFIs in Bangladesh can show their real performance, in future capital market would be the most likely destination for their funding needs.

The cost of funding by NBFIs is significantly higher than the banks as banks are the prime sources of funds for them. According to industry insiders, leasing companies depend on bank finance for their business: small companies depend 100 percent on banks while the larger ones depend 60 percent to 70 percent (Rahman, 2010). Cost still continues to plague the NBFIs since the perception of the general people still continues to favor the banks against non banks. At present, with high cost of funds non-banks are forced to compete with the banks those have relatively low cost of funds. This situation somewhat hampers the growth and development of NBFIs. In most of the cases, the rate differential for deposits appears to be around $2 \%$ higher for non banks (Khan, 2010). There is some scope of NBFIs to have low cost funds with several refinancing schemes in the SME, Agricultural, Information Technology, Alternate Energy and development of women entrepreneurs. In order to reduce the funding cost from traditional banks for meeting their working capital requirements, some of the financial institutions have already introduces new financial instruments like bonds, Asset Securitization and sourcing from overseas Development Financial Institutions (DFIs). In their study, Banerjee and Mamun (2003) showed that weighted average cost of funds for the NBFIs is always higher than that of banks. Their report revealed that, cost of funds for leasing companies varied between 8.4 to 15.3 percent while that of banks was between 8.5 to 9.5 percent. Choudhury (2001) mentioned that about 15 percent of the deposit of the banking sector was reported to be demand deposits, which are interest free while 35 percent constituted low cost saving deposits having an average of 4 to 5 percent

Copyright $($ 2013, Asian Business Consortium | ABR interest rate and the rest were fixed deposits bearing an average of 9 percent interest rate. Thus, the weighted average cost of fund for banks would be at best 7 to 8 percent, which is almost half of that of NBFIs.

NBFIs face several problems while generating funds from different sources. The demand for funds to meet the increasing requirement has increased manifold. The availability of funds from banks is becoming inadequate day by day due to the involvement of banks with some similar functions of NBFIs. Inefficient capital market and the lack of established secondary market are not providing good message to the investors to relay on the market by which NBFIs can raise a substantial amount of capital through issuing shares, bonds and other securities, even the zero coupon bond subscribed by NBFIs are not tax exempted. External commercial borrowings are also appears to be not promising for our economy. Financial institutions can attract the depositors to raise funds through offering deposit products of different maturities to gain better access to public deposits. But NBFIs are not allowed to accept deposit less than 6 months maturity. Overnight borrowings are not an encouraging proposition for the NBFIs due to the cash flow mismatch. On the other hand, due to the liquidity crisis, when interest rate goes up, the average rate of interest on bank credit lines and deposit rate also increases, which causes significant rise in the cost of funds for NBFIs. Again, it is also high risky for taking long-term foreign currency loan because of exchange rate fluctuations and lack of absorptions scheme against fluctuation.

Cost of funding is a function of the composition of liabilities and the costs of raising the different liabilities. Primarily the cost of funds depends on the demand for and the supply of the availability of funds. There are several factors that affect cost of funds for non banks. These factors are broadly categories as external and internal factors and may influence directly or indirectly. External factors include nation's money supply, inflation, personal income, retail sales, opportunity to deposit elsewhere, deposit interest rate differential and so on. On the other hand, the internal factors that may affect cost of funds may include volume and types of deposit, loan and lease amount, capital, total asset size, return on asset, etc.

This paper is divided into six sections. After a brief background as part of introduction, section two highlights the objectives of the study. Section three defines the methodology and section four reveals the current status of some selected variables for NBFIs and comparison with BFIs. Section five represents the findings \& analysis of the results and, finally, section six presents the conclusion.

\section{OBJECTIVE OF THE STUDY}

Against the above background, this paper examines the present scenario of cost of funds for non bank financial institutions in Bangladesh and tried to identify the internal factors, if any; that may influence their cost of funds. Thus the specific objectives of the paper are: 
1. to identify the current scenario of the cost of funds of different groups of NBFIs, and

2. to find out whether internal factors affect the cost of funds of NBFIs in Bangladesh.

\section{Methodology}

\subsection{SAMPLING AND DATA COLLECTION}

The study considers quantitative data collected from the secondary sources. As an authentic source, data are collected from the audited financial statements of NBFIs published in the annual reports for the year 2008 to 2011. Besides, published literature, research papers, different books were reviewed to complete the theoretical background and relevant websites were visited to collect other secondary information. There are two stock exchanges in Bangladesh - Dhaka Stock Exchange (DSE) and Chittagong Stock Exchange (CSE). Most of the cases, companies listed on CSE are also listed on DSE. Therefore, the study covers the NBFIs listed on DSE. A total number of twenty NBFIs were listed on DSE in the selected period (DSE, 2012). Based on purposive sampling a total sixteen NBFIs are taken into consideration for the research purpose as per the availability of the published annual reports. Thus, sample covers $80 \%$ of the population. Appendix I represents the sample companies.

\subsection{VARIABLES AND HyPOTHESIS DEVELOPMENT}

One of the objectives of this study is to find out internal factors affecting the cost of funds of NBFIs in Bangladesh. Therefore, the dependent variable is the cost of funds (COF) of NBFIs. A number of internal factors are identified to show their influence on the COF of NBFIs in Bangladesh. These internal factors include age of business $(\mathrm{AB})$, equity contribution (EC), size of business (SB), nature of assets (NA) and profitability (PR) which are considered as independent variables.

\section{Age of business}

Age of business (AB) is measured on the basis of establishment year of the firms. The firm, which is old, can collect funds in low cost because of their bonding depositors and market reputation. In this regard, firms are classified into three categories: firms established before the year 1990 grouped as 'very old' firms; firms established during 1991-2000 are 'old' the firms established after 2000 are 'new' firms. Thus, the study infers a negative relationship between the age of the firm and the COF.

\section{Equity contribution}

Equity contribution (EC) in the business absorbs risk of the other contributors. If equity contribution in the business is higher than the external fund providers fill less risk for their investments. As a result, they may show their interest to provide funds to the business with low rate of return as the charge of their risk premium is low. Total paid-up capital (PC) is considered in the study as the equity contribution. Therefore, the hypothesis drawn for this variable is that equity contribution has negative impact on the COF of the firm.

\section{Size of business}

Size of business (SB) may be measured by sales, assets, number of employees, etc. For this study, amount of total assets (TA) is used as a proxy of business size. It is expected that, if the total size of the firms are large they can mobilize funds with low cost. Because, it indicates that the firm has the ability to repay the borrowed funds and can achieve the confidence of the depositors and others. Thus, the study infers a negative association between the size of business and $\mathrm{COF}$ of the firm.

\section{Nature of assets}

Nature of assets (NA) of the firm, a new variable, is used in this study measured by interest earning assets to total assets (IEA). If the firm invests more in interest earning assets, it ensures more earnings for the firm which indicates the firm's liquidity and capacity. In this circumstance, depositors may get the confidence and feel less risk to deposit their money even with a low rate of return compared to the firms exhibiting high non interest earning assets. Hence, a negative association between NA and COF is expected.

\section{Profitability}

Profitability is an important independent variable for this study. It is expected that firms with higher profitability may collect low cost funds because of their market goodwill and repayment capacity. In the present study, the earning per share (EPS) has been used as a measure of profitability and is expecting that there is a negative association between COF and the earning per share.

Based on the above discussions regarding the variables used in the study following hypothesis is developed for the analysis:

$\mathrm{H}_{1}$ : Age of business, equity contribution, size of business, nature of assets and profitability have significant impact on the cost of funds of non-bank financial institutions in Bangladesh.

\subsection{DATA ANALYSIS AND TEST OF HYPOTHESIS}

For tabulating and summarizing data, Microsoft Excel 2007 is used. For the purpose of empirical analysis, the linear regression model is developed to identify the relationship of the internal factors with the cost of funds. SPSS 14.0 version is used in this regard. Appendix II presents the operational definition of variables along with expected sign. The regression technique used to test $\mathrm{H}_{1}$ is as follows:

$$
\mathrm{COF}=\alpha+\beta_{1} \mathrm{X} 1+\beta_{2} \mathrm{X} 2+\beta_{3} \mathrm{X} 3+\beta_{4} \mathrm{X} 4+\beta_{5} \mathrm{X} 5+\varepsilon
$$
Expected sign: (-)
$(-)$
$(-)$
$(-)$
$(-)$

Where:
$\mathrm{COF}=$ Cost of funds
$\mathrm{X} 1=\mathrm{AB}$, representing the age of business
$\mathrm{X} 2=\mathrm{EC}$, representing equity contribution measured by log of paid up capital




$$
\begin{aligned}
& \mathrm{X} 3=\mathrm{SB} \text {, representing size of business measured by log } \\
& \text { of total asset } \\
& \mathrm{X} 4=\mathrm{NA} \text {, representing nature of assets, indicates pro- } \\
& \text { portion of interest earning asset } \\
& \text { X5 = PR, representing profitability, indicates earning } \\
& \text { per share } \\
& \alpha=\text { constant } \\
& \beta_{\mathrm{j}} \quad=\text { coefficient of the concern variables }(\mathrm{j}=1 \text { to } 5) \\
& \varepsilon \quad=\text { the error term }
\end{aligned}
$$

\section{Current Status of NBFIs and Comparison WITH BFIS}

The cost of funds is one of the most important input costs for a financial institution, since a lower cost will generate better returns when the funds are deployed in the form of shortterm and long-term loans to borrowers. The spread between the cost of funds and the interest rate charged to borrowers represents one of the main sources of profit for most financial institutions. Generally, the cost of funds depends on the sources of funds and the availability of funds from those particular sources. According to the Financial Stability Report of Bangladesh Bank (2011), the borrowing, deposits and capital of NBFIs increased by 13.5 percent, 16.6 percent and 34.5 percent respectively in year 2011 compared with those of the precious year. The trend of increasing capital shows a healthy financial base of the NBFIs. Table 1 shows the status of some selected variables of NBFIs for the last four years those are used in the regression model of the study. From the table it is observed that the average cost of funds for the listed NBFIs was $13.14 \%$ in the year 2008 and gradually reduced for the next two years which are $11.78 \%$ and $11.20 \%$ respectively. However, in 2011, this rate jumped to $13.72 \%$ and the CAGR of the COF is $1.09 \%$.

Table 1: COF, EC, SB, NA and PR of NBFIs in Bangladesh

\begin{tabular}{|c|c|c|c|c|c|}
\hline & COF & EC & SB & NA & PR \\
\hline 2008 & 13.14 & 364.487 & 6319.881 & 90.233 & 36.521 \\
\hline 2009 & 11.78 & 417.733 & 8094.512 & 89.688 & 59.401 \\
\hline 2010 & 11.20 & 580.199 & 9951.333 & 87.939 & 67.193 \\
\hline 2011 & 13.72 & 935.637 & 10871.235 & 87.420 & 25.823 \\
\hline Average & 12.46 & 574.514 & 8809.240 & 88.820 & 47.234 \\
\hline SD & 1.167 & 257.639 & 2021.876 & 1.352 & 19.318 \\
\hline CV & 0.094 & 0.448 & 0.230 & 0.015 & 0.409 \\
\hline CAGR & 1.09 & 26.58 & 14.52 & -0.79 & -8.30 \\
\hline
\end{tabular}

Source: Authors' own calculation, Data: Annual Report of respective NBFI

The four-year average COF for Fidelity Assets and Securities Company Ltd was higher $(14.38 \%$ ) and lower COF was $11.29 \%$ for Industrial Promotion and Development Company of Bangladesh Ltd which is shown in Appendix III. The average cost of funds for all the listed NBFIs was $12.46 \%$ for the last four years with a standard deviation of 1.16 although some company experiences some higher rate. For example, in 2011, the cost of funds for Fidelity Assets and Securities Company Ltd was $17.18 \%$, which was highest for the industry. The equity contribution of the listed NBFIs has increased from year 2008 to 2011 with the CAGR of $26.58 \%$. At the same time, the size of their total asset has also increased where the CAGR is $14.52 \%$. These two variables indicate that in future NBFIs may attract the funds supplier to raise low cost funds for their business operation. Although the size of total asset has increased, the amount of total earning asset has reduced with a negative CAGR of $-0.79 \%$ which greatly impact on their earning per shares (EPS) that are also experiences a negative CAGR of $-8.30 \%$. Thus, if the listed NBFIs do not increase their earning asset to overcome the current situation immediately, in future they will fail to attract the internal as well as external funds provider with a reasonable cost.

As the sources of funds are different for banks and NBFIs, the funding cost is also different. For banking sector, deposits are the largest source of external funds. According to the Financial Stability Report of Bangladesh Bank (2011), the share of total deposits was 85.5 percent of the total liabilities as at end-December 2011. Compared with the 2010, deposits of all banks have increased 21.2 percent in the year of 2011. On the other hand, the major funding sources of NBFIs are capital, term deposit, credit facilities from banks and other FIs and also bonds and securitization. The deposits of NBFIs increased by 16.6 percent in year 2011 compared to year 2010 and the share of total deposit was 51.17 percent of the total liabilities at 2011.

Table 2 shows the comparative statistics both for banking sectors and for NBFIs in regard to their total shareholders' equity, deposits, borrowing from other banks/FIs and cost of funds from year 2007 to 2011. According to the table, the compound annual growth rate (CAGR) of the shareholders' equity during 2007 to 2011 for the NBFIs is 35.49 percent with CV of 51.23 percent, whereas for banking sectors the CAGR is 32.50 percent and the CV is 49.39 percent. Although the amount holding of NBFIs is only 9.80 percent of total in 2011, the growth rate indicates that gradually they are trying to depend on the capital market for fulfilling their funding requirements.

The total size of deposits for NBFIs is increasing day by day with a CAGR of 26.81 percent during 2007-2011. At the same time, it is observed that the CAGR of borrowing from other bank/FIs is negative. However, compared to 2010, growth rate of borrowing for NBFIs is 13.46 percent in 2011. The positive CAGR of deposits and the negative CAGR of borrowing indicate that NBFIs are trying to increase their deposit base and reduce the bank borrowing which will affect their cost of funds favorably. A CAGR of BFIs deposit is 19.92 percent, which is less than the NBFIs with the SD of 29.93 percent as NBFIs are competing with the BFIs in this regard. 
Table 21: Shareholders' equity, Deposit, Borrowings and COF of NBFIs and BFIs (Tk. in Billion)

\begin{tabular}{|c|c|c|c|c|c|c|c|c|}
\hline \multirow[t]{2}{*}{ Year } & \multicolumn{2}{|c|}{$\begin{array}{c}\text { Shareholders' } \\
\text { equity }\end{array}$} & \multicolumn{2}{|c|}{ Deposit } & \multicolumn{2}{|c|}{$\begin{array}{l}\text { Borrowings } \\
\text { from other } \\
\text { banks/FIs }\end{array}$} & \multicolumn{2}{|c|}{$\begin{array}{l}\text { Cost of } \\
\text { Funds* }\end{array}$} \\
\hline & NBFIs & BFIs & NBFIs & BFIs & NBFIs & BFIs & NBFIs & BFIs \\
\hline \multirow{2}{*}{2007} & 17 & 171 & 45 & 2212 & 79 & $\mathrm{~N} / \mathrm{A}$ & 9.51 & 6.84 \\
\hline & $(9.04)$ & (90.96) & $(2.00)$ & (98.00) & $(100.00)$ & $\mathrm{N} / \mathrm{A}$ & & \\
\hline \multirow{2}{*}{2008} & 20 & 180.8 & 55 & 2608.9 & 60 & 120.2 & 10.2 & 7.09 \\
\hline & $(9.96)$ & $(90.04)$ & (2.06) & $(97.94)$ & (33.30) & $(66.70)$ & & \\
\hline \multirow{2}{*}{2009} & 27.6 & 272.7 & 84.1 & 3130.6 & 49.4 & 122 & 9.6 & 6.29 \\
\hline & (11.26) & $(88.74)$ & $(2.62)$ & $(97.38)$ & $(28.82)$ & $(71.18)$ & & \\
\hline \multirow{2}{*}{2010} & 42.6 & 418.7 & 99.8 & 3781.6 & 69.1 & 159.8 & 9.7 & 6.08 \\
\hline & $(9.23)$ & $(90.76)$ & $(2.57)$ & (97.43) & (30.19) & $(69.81)$ & & \\
\hline \multirow{2}{*}{2011} & 57.3 & 527.1 & 116.4 & 4575.1 & 78.4 & 226.3 & 10.9 & 7.52 \\
\hline & $(9.80)$ & $(90.20)$ & $(2.48)$ & $(97.52)$ & (25.73) & $(74.27)$ & & \\
\hline CAGR $^{* *}$ & 35.49 & 32.50 & 26.81 & 19.92 & -0.19 & 23.47 & 3.46 & 2.39 \\
\hline SD & 16.85 & 155.13 & 29.93 & 940.81 & 12.61 & 49.63 & 0.57 & 0.58 \\
\hline CV (\%) & 51.23 & 49.39 & 37.38 & 28.84 & 18.78 & 31.59 & 5.79 & 8.67 \\
\hline
\end{tabular}

Source: Authors' own calculation, Data: Financial Stability Report 2011 of Bangladesh Bank

In terms of cost of funds, table 2 shows the cost of deposit for BFIs as cost of funds did not available and cost of deposits and borrowing for NBFIs. Since 85.5 percent of BFI's total liabilities are deposits, this can widely represents the cost of funds. The CAGR of cost of funds for NBFIs is 3.46 percent during 2007-2011 with CV of 5.79 percent. Thus the cost of funds is increasing day by day. The cost of funds for BFIs also increases as CAGR is 2.39 percent but it is less than the NBFIs. As the cost of funds for BFIs rises, the cost of funds for NBFIs also increases.

\section{Findings ANd AnALysis of the Results}

The first objective of the study is to identify the current scenario of the cost of funds of different groups of NBFIs. To comply with this objective, NBFIs are grouped on the basis of establishment year and the nature of their ownership. The results of the selected variables are discussed according to their groups. On the other hand, the second objective is to find out the causal relationship of the internal factors with the cost of funds of NBFIs. The results of the regression analysis are also discussed in this section.

\subsection{DESCRIPTIVE ANALYSIS}

Table 3 shows the Cost of Funds, Equity Contribution,

\footnotetext{
${ }^{1}$ Note:

*Cost of funds indicate cost of deposits for BFIs and cost of deposit and borrowing for NBFIs

**Compound Annual Growth Rate

- N/A stands for not available

- Figures in parentheses indicate percentage of participation in total combining figures of NBFIs and BFIs
}

Size of Business and Profitability ratio of NBFIs. Listed NBFIs are divided into three groups on the basis of their establishment year (before 1990, during 1991-2000 and after 2000). According to the table, it is found that the average cost of funds of NBFIs established before 1990 is lower compared to other two groups and NBFIs established after 2000 exhibit the higher COF. As the group of old firm has market reputation with large asset size and higher capital contribution, they can collect funds with lower rate. The CAGR of NBFIs established before 1990 is negative $(-0.57 \%)$ with the $\mathrm{CV}$ of $8 \%$ indicating that the cost of funds has decreased over the period of time. The average COF of NBFIs established after 2000 shows the highest rate of $13.72 \%$ with the CAGR of $1.82 \%$ which means that they involve high rate to raise their funds.

The average equity contribution of NBFIs established before 1990 represent the highest among all the groups that is Tk. 616.20 million and the CAGR is $24.44 \%$ indicating their financial soundness that may help them to collect funds at a favorable cost. Although this figure is not highest for the NBFIs established during 1991-2000, the CAGR is 30.03\% which is the highest among all groups. On the other hand, the average equity contribution of NBFIs established after 2000 is Tk. 438.25 million and the CAGR is only $15.44 \%$. The size of total asset for NBFIs established before 1990 is higher but the CAGR of NBFIs established during 1990-2000 represent the highest $(17.55 \%)$. The profitability ratios (measured by the earning per share) represent the negative CAGR for both the group of NBFIs established before 1990 and during $1991-2000$, but the CAGR is $13.77 \%$ for the last group although the other two groups demonstrate the large absolute figure. From the above discussion, it is clear that NBFIs established before 1990 shows higher equity contribution and total asset size. At the same time, the low COF with negative CAGR implies their ability to generate funds at a low cost for the reputation and public confidence.

Table 4 shows the Cost of Funds, Equity Contribution, Size of Business and Profitability ratio of NBFIs groups based on their ownership structure. According to this structure, NBFIs are divided into local and joint venture groups. According to the table, the rate of average COF for the NBFIs of both local and joint venture groups shows almost the same although the CAGR of local NBFIs is slightly higher $(1.22 \%)$. The average equity contribution of the group of joint venture NBFIs is higher, but the CAGR is almost the same for both the groups. In terms of the size of business, the group of joint venture NBFIs achieves higher CAGR $(15.21 \%)$ during the particular period of time. The average earning per share is higher for the group of joint venture NBFIs which is Tk. 48.54. However, both the groups demonstrate the negative CAGR for the EPS. Thus, it is observed that due to the high equity contribution, large asset size and high EPS of the group of joint venture NBFIs compared to local NBFIs are able to raise relatively low cost funds. 
Table 3: Comparative COF, EC, SB and PR of NBFIs based on Establishment Year

\begin{tabular}{|c|c|c|c|c|c|c|c|c|c|c|c|c|}
\hline & \multicolumn{2}{|c|}{ COF } & \multicolumn{3}{|c|}{ EC (Tk. In millions) } & \multicolumn{2}{c|}{ SB (Tk. In millions) } & \multicolumn{3}{c|}{ PR } \\
\hline & $\begin{array}{c}\text { Before } \\
1990\end{array}$ & 2000 & $\begin{array}{c}\text { ffter } \\
2000\end{array}$ & $\begin{array}{c}\text { Before } \\
1990\end{array}$ & $\begin{array}{c}1991- \\
2000\end{array}$ & $\begin{array}{c}\text { After } \\
2000\end{array}$ & $\begin{array}{c}\text { Before } \\
1990\end{array}$ & $\begin{array}{c}1991- \\
2000\end{array}$ & $\begin{array}{c}\text { After } \\
2000\end{array}$ & $\begin{array}{c}\text { Before } \\
1990\end{array}$ & $\begin{array}{c}1991- \\
2000\end{array}$ & $\begin{array}{c}\text { 2fter } \\
2000\end{array}$ \\
\hline $\mathbf{2 0 0 8}$ & 12.44 & 13.14 & 13.81 & 397.88 & 357.55 & 354.20 & 10862.69 & 5602.21 & 4169.30 & 68.89 & 32.77 & 16.66 \\
\hline $\mathbf{2 0 0 9}$ & 11.33 & 11.49 & 13.21 & 449.31 & 423.89 & 365.64 & 12555.81 & 7576.98 & 5358.31 & 116.50 & 53.67 & 21.41 \\
\hline $\mathbf{2 0 1 0}$ & 10.30 & 10.92 & 13.03 & 663.44 & 608.07 & 404.05 & 14143.89 & 9706.26 & 6575.68 & 74.78 & 66.20 & 62.92 \\
\hline $\mathbf{2 0 1 1}$ & 12.16 & 13.85 & 14.85 & 954.18 & 1022.04 & 629.09 & 16076.90 & 10695.13 & 6252.58 & 28.47 & 24.40 & 27.92 \\
\hline Ave. & 11.56 & 12.35 & 13.72 & 616.20 & 602.89 & 438.25 & 13409.82 & 8395.15 & 5588.97 & 72.16 & 44.26 & 32.23 \\
\hline SD & 0.96 & 1.37 & 0.82 & 252.96 & 298.85 & 129.005 & 2226.31 & 2271.47 & 1077.44 & 36.02 & 19.11 & 20.97 \\
\hline CV & 0.08 & 0.11 & 0.06 & 0.411 & 0.496 & 0.294 & 0.16 & 0.27 & 0.19 & 0.49 & 0.43 & 0.65 \\
\hline CAGR & -0.57 & 1.31 & 1.82 & 24.442 & 30.03 & 15.44 & 10.29 & 17.55 & 10.66 & -19.82 & -7.11 & 13.77 \\
\hline
\end{tabular}

Source: Authors' own calculation, Data: Annual Report of respective NBFI

Table 4: Comparative COF, EC, SB and PR of NBFIs based on Ownership.

\begin{tabular}{|l|c|c|c|c|c|c|c|c|}
\hline & \multicolumn{2}{|c|}{ COF } & \multicolumn{2}{c|}{ EC } & \multicolumn{2}{c|}{ SB } & \multicolumn{2}{c|}{ PR } \\
\hline & Local & JV & Local & JV & Local & JV & Local & JV \\
\hline 2008 & 12.87 & 13.18 & 276.86 & 377.01 & 6285.37 & 6324.81 & 35.56 & 36.66 \\
\hline 2009 & 12.31 & 11.71 & 312.72 & 432.74 & 6855.56 & 8271.51 & 44.72 & 61.50 \\
\hline 2010 & 11.19 & 11.20 & 485.38 & 593.75 & 7860.53 & 10250.02 & 59.11 & 68.35 \\
\hline 2011 & 13.51 & 13.75 & 738.73 & 963.77 & 8963.44 & 11143.78 & 12.90 & 27.67 \\
\hline Average & $\mathbf{1 2 . 4 7}$ & $\mathbf{1 2 . 4 6}$ & $\mathbf{4 5 3 . 4 2}$ & $\mathbf{5 9 1 . 8 1}$ & $\mathbf{7 4 9 1 . 2 2}$ & $\mathbf{8 9 9 7 . 5 3}$ & $\mathbf{3 8 . 0 7}$ & $\mathbf{4 8 . 5 4}$ \\
\hline SD & $\mathbf{0 . 9 8}$ & $\mathbf{1 . 2 0}$ & $\mathbf{2 1 0 . 8 6}$ & $\mathbf{2 6 4 . 4 5}$ & $\mathbf{1 1 7 7 . 8 4}$ & $\mathbf{2 1 4 8 . 3 1}$ & $\mathbf{1 9 . 3 8}$ & $\mathbf{1 9 . 4 7}$ \\
\hline CV & $\mathbf{0 . 0 8}$ & $\mathbf{0 . 1 0}$ & $\mathbf{0 . 4 7}$ & $\mathbf{0 . 4 5}$ & $\mathbf{0 . 1 6}$ & $\mathbf{0 . 2 4}$ & $\mathbf{0 . 5 1}$ & $\mathbf{0 . 4 0}$ \\
\hline CAGR & $\mathbf{1 . 2 2}$ & $\mathbf{1 . 0 7 4}$ & $\mathbf{2 7 . 8 1}$ & $\mathbf{2 6 . 4 5}$ & $\mathbf{9 . 2 8}$ & $\mathbf{1 5 . 2 1}$ & $\mathbf{- 2 2 . 3 9}$ & $\mathbf{- 6 . 7 9}$ \\
\hline
\end{tabular}

Source: Authors' own calculation, Data: Annual Report of respective NBFI

\subsection{MuLtiPLE REgRESSION ANALYSIS}

This study runs a regression model to identify the impact, if any, of internal factors on the cost of funds for NBFIs. For this analysis five internal factors are selected like age of business $(\mathrm{AB})$, equity contribution of the owners (EC), size of business (SB), nature of business (NA) and profitability (PR). In the regression equation, the log of total paid up capital is considered for the equity contribution, the $\log$ of total asset is considered for the size of business, the proportion of interest earning asset is considered for the nature of asset and finally the earning per share is used for the profitability measurement. The descriptive statistics of the sample firms are shown in table 5. According to the table, the maximum COF for the listed NBFIs are $17.18 \%$ and the minimum is $9.75 \%$ that results the average COF of 12.46 with a standard deviation of 1.50 . In terms of the age of the firms, the maximum age is 30 where the minimum age is only 6 . For this age, variation firms are experiencing different cost of funds. The ratio of interest earning asset to total asset which is used as the nature of asset shows the maximum of $98.04 \%$ and the minimum of $64.19 \%$ with the standard deviation of 8.15 that indicates that most of the firms have more asset but the size of their non earning assets are high. On the other hand, the maximum EPS of the listed NBFIs are 273.93 and the minimum is -5.60 with a standard deviation of 43.89 . From the earliest analysis it is found that NBFIs established after 2000 experiences low EPS than the other two groups which makes the greater standard deviation.

Table 5: Descriptive Statistics of the variables

\begin{tabular}{|c|c|c|c|c|c|}
\hline Variable & $\mathbf{N}$ & Minimum & Maximum & Mean & $\begin{array}{l}\text { Std. } \\
\text { Deviation }\end{array}$ \\
\hline COF & 64 & 9.75 & 17.18 & 12.4599 & 1.50414 \\
\hline AGE & 64 & 6.00 & 30.00 & 14.1875 & 5.67611 \\
\hline EC & 64 & 4.62 & 7.55 & 6.2072 & .53721 \\
\hline SB & 64 & 7.16 & 10.35 & 8.8757 & .68049 \\
\hline NA & 64 & 64.19 & 98.04 & 88.8192 & 8.14992 \\
\hline PR & 64 & -5.60 & 273.96 & 47.2343 & 43.89665 \\
\hline
\end{tabular}

Source: Authors' own calculation

Table 6 represents the results of the multiple regression analysis. From the table it is clear that the value of $R$ Square is .520 and the adjusted $R$ square is .437. Since the analysis is done by considering only the internal factors, 92 | P a g e 
$52 \%$ of the depended variable (COF) is explaining the set of independent variables used in the model. The value of $\mathrm{F}$ is 4.298 and is significant at .002 levels. To assess the potential for multicollinearity, regression analysis of variance inflation factors (VIF) and tolerance levels have performed. Since all values of tolerance levels are greater than 0.10 , there is no such problems of multicollinearity that may create harmful effects in the model (Menard, 1995). Weisberg (1985) suggests that multicollinearity in explanatory variables has been diagnosed through analysis of VIF. Myers (1990) suggests that where the VIF for the independent variables is greater than 10 , these should be considered an indication of harmful multicollinearity. In the present study, all of the VIFs for independent variables are less than 10, indicating that multicollinearity between the independent variables is unlikely to create a serious problem in interpreting the results of the regression analysis.

Table 6: Regression Results

\begin{tabular}{|c|c|c|c|c|c|c|}
\hline Variable & $\begin{array}{c}\text { Beta } \\
\text { Coefficient }\end{array}$ & $\begin{array}{c}\text { Std. } \\
\text { Error }\end{array}$ & $\begin{array}{c}\text { Beta t } \\
\text { values }\end{array}$ & $\begin{array}{c}\text { Signifi } \\
\text { cance }\end{array}$ & \multicolumn{2}{|c|}{$\begin{array}{c}\text { Collinearity } \\
\text { Statistics }\end{array}$} \\
\hline (Constant) & 14.654 & 2.793 & 5.246 & .000 & $\begin{array}{c}\text { Toler } \\
\text { ance }\end{array}$ & VIF \\
\hline AGE & -.083 & .032 & -2.587 & $.012^{*}$ & .856 & 1.168 \\
\hline EC & -.112 & .387 & -.290 & .773 & .658 & 1.519 \\
\hline NA & -.021 & .023 & -.904 & .370 & .482 & 2.076 \\
\hline PR & -.012 & .005 & -2.408 & $.019^{*}$ & .831 & 1.204 \\
\hline SB & .235 & .357 & .657 & .514 & .576 & 1.736 \\
\hline $\begin{array}{l}\text { R Square }=.520 \\
\text { Adjusted R Square }=.437 \\
\text { F value }=4.298 \\
\text { Significance }=.002\end{array}$
\end{tabular}

Source: Authors' own calculation

Table 6 shows that, out of five independent variables two are statistically significant at 5\% level conforming to the expected sign. These two factors are the age and the earnings per share. As a result, it can be said that the age and profitability (measured by earnings per share) are strong factors that are greatly influencing the COF of NBFIs and are negatively related with COF. Therefore, NBFI with high earnings per share and relatively old aged can collect low cost funds and vice versa. Although the other two variables equity contribution (measured by paid up capital) and nature of asset (measured by proportion of interest earning asset) are not statistically significant, they are conforming the expected sign. Thus, it indicates that firm with high paid up capital and large earning per share can attract the funds provider which may reduce their COF. These results also support the previous analysis (Table 3) of the study. The other variable size of business that is measured by total asset is providing the conflicting result. This variable neither conform the expected sign nor is statistically significant.

\section{CONCLUSION}

NBFIs are playing an important role along with the banking sector to ensure the sustainable development of our economy. Over the last few years, NBFIs are competing with the BFIs in different aspects especially in lending and deposit mobilization. Recently banks are increasingly moving into the domain of non-banks and have been increasingly taking over much of the role of the non-banks as they have the advantage of lower costs of fund compared to the NBFIs. On the other hand, NBFIs are suffering from high cost and scarcity of funds. This situation somewhat hampers the growth and development of NBFIs. This study tried to identify the COF of different groups of NBFIs and finds that the group of NBFIs establish before 1990 experiences a low COF due to the high age, more paid up capital, large asset size and more earning per shares, etc. compared to the NBFIs established during 1991-2000 and after 2000. On the other hand, due to the high equity contribution, large asset size and high EPS of the group of joint venture NBFIs compared to local NBFIs are able to raise relatively low cost funds.

The study also examines the impact of internal factors, if any, on the overall cost of fund for DSE listed NBFIs. To identify the relationship with $\mathrm{COF}$, five internal factors are used and the model suggested that the independent variables can explained the $\mathrm{COF}$ as $52 \%$ with the $\mathrm{F}$ value of 4.293 at .002 levels of significance. From the regression analysis it is found that the age and profitability (measured by earnings per share) factors have strong influence on COF of NBFIs and are negatively related with the dependent variable. Therefore, NBFI with high earnings per share and relatively old aged can collect low cost funds and vice versa. The other two variables equity contribution (measured by paid up capital) and nature of asset (measured by proportion of interest earning asset) are not statistically significant, but they are conforming the expected sign indicating that firm with high paid up capital and large earning per share can attract the funds provider which may reduce their COF. The other variable size of business that is measured by total asset, neither conform the expected sign nor is statistically significant. Since the study conducted on the basis of internal factors and a very few literature are available in the field, further study can be conducted with some other external factors to identify the most influential and statistically significant variables those may greatly explain the cost of funds. 


\section{REFERENCES}

Ahmed, Md. Nehal and Chowdhury, Mainul Islam (2007), "NonBank Financial Institutions in Bangladesh: An Analytical Review", Working Paper Series: WP 0709, Research Department, Bangladesh Bank, Dhaka.

Banerjee, P. K. and Mamun, Ashraf Al (2003), "Lease Financing in Bangladesh", BIBM Research Paper.

Bangladesh Bank (2012), Financial Stability Report 2011, Issue 2, Dhaka.

Choudhury A. Q. (2001), "Leasing in Bangladesh - Problems and Prospects", The Daily Star, April 4, 2001.

Chowdhury A. Jalil. (1999), "An Appraisal of Non-Banking Financial Institutions in the Context of Economic Development of Bangladesh", Bank Parikrama, Vol. 24, No. 1, pp 171-194.

Goldsmith, R.W. (1969), Financial Structure and Development, Yale University Press, London.

Hossain, Monzur and Shahiduzzaman, Md. (2002), "Development of Non Bank Financial Institutions to Strengthen the Financial System of Bangladesh", available at mpra.ub.unimuenchen.de/24734/1/0409006.pdf

Khan, Asad (2010), "An Overview of Financial Sector and Leasing Industry in Bangladesh" Year book 2010, Bangladesh Leasing and Finance Companies Association, Dhaka.

Rahman, Sajjadur (2010), "Leasing firms, banks in turf war", The Daily Star, Thursday, April 8, 2010.

Reserve Bank of India (2011), Report on Trend and Progress of Banking in India 2010-11, "Chapter VI, Non-Banking Financial Institutions", available at www.scribd.com/doc/75551133/BankingProgress-Report.

Saha, Sujit, Barai, Munim K., and Mamun, Ashraf. Al. (1999), "Progress and Prospects of Non-Bank Financial Institutions in Bangladesh", Bank Parikrama, Vol. 24, No. 1, pp 130-165.

\section{Appendix I: List of Sample Firms}

\begin{tabular}{|c|l|c|c|}
\hline S1. & Name of NBFIs & $\begin{array}{c}\text { Short } \\
\text { Name }\end{array}$ & $\begin{array}{c}\text { Year of } \\
\text { Establi } \\
\text { shment }\end{array}$ \\
\hline 1 & $\begin{array}{l}\text { Industrial Promotion and Development } \\
\text { Company of Bangladesh Ltd (IPDC) }\end{array}$ & IPDC & 1981 \\
\hline 2 & $\begin{array}{l}\text { Industrial Development leasing Company } \\
\text { of Bangladesh Ltd (IDLC) }\end{array}$ & IDLC & 1985 \\
\hline 3 & United Leasing Company Ltd (ULCL) & ULCL & 1989 \\
\hline 4 & Phoenix Leasing Company Ltd & PLCL & 1995 \\
\hline 5 & $\begin{array}{l}\text { International Leasing and Financial Ser- } \\
\text { vices Ltd (ILFSL) }\end{array}$ & ILFSL & 1996 \\
\hline 6 & Prime Finance and Investment Ltd. & PFIL & 1996 \\
\hline 7 & Bay Leasing and Investment Ltd & BAYLI & 1996 \\
\hline 8 & Peoples Leasing and Financial Services Ltd. & PLFSL & 1996 \\
\hline 9 & First Lease International Ltd & FLIL & 1996 \\
\hline 10 & Lanka Bangla Finance Ltd. & LBFL & 1997 \\
\hline 11 & Bangladesh Industrial Finance Company Ltd & BIFC & 1998 \\
\hline 12 & Union Capital Ltd (UCL) & UCL & 1998 \\
\hline 13 & $\begin{array}{l}\text { National Housing Finance and Invest- } \\
\text { ments Ltd }\end{array}$ & NHFI & 1998 \\
\hline 14 & $\begin{array}{l}\text { Industrial and Infrastructure Develop- } \\
\text { ment Finance Company Ltd (IIDFCL) }\end{array}$ & IIDFCL & 2001 \\
\hline 15 & Fidelity Assets and Securities Company Ltd & FIASCL & 2001 \\
\hline 16 & Premier Leasing International Ltd & PLIL & 2002 \\
\hline
\end{tabular}

Appendix II: Operational Definition of Variables along with Expected Sign

\begin{tabular}{|l|l|l|l|}
\hline Variable & Definition & Measurement & $\begin{array}{l}\text { Expected } \\
\text { Sign }\end{array}$ \\
\hline COF & Cost of fund & $\begin{array}{l}\text { Dependent } \\
\text { Variable }\end{array}$ \\
\hline AB & Age of business & Based on establishment year & $(-)$ \\
\hline EC & $\begin{array}{l}\text { Equity contribu- } \\
\text { tion }\end{array}$ & $\begin{array}{l}\text { Measured by natural log of } \\
\text { total paid-up capital }\end{array}$ & $(-)$ \\
\hline SB & Size of business & $\begin{array}{l}\text { Measured by natural log of } \\
\text { total assets }\end{array}$ & $(-)$ \\
\hline NA & Nature of assets & $\begin{array}{l}\text { Measured by interest earn- } \\
\text { ing assets to total assets }\end{array}$ & $(-)$ \\
\hline PR & Profitability & $\begin{array}{l}\text { Measured by earning per } \\
\text { share }\end{array}$ & $(-)$ \\
\hline
\end{tabular}

\section{Appendix III: COF of NBFIs for the last four Years}

\begin{tabular}{|c|c|c|c|c|c|c|c|}
\hline NBFI & $\mathbf{2 0 0 8}$ & $\mathbf{2 0 0 9}$ & $\mathbf{2 0 1 0}$ & $\mathbf{2 0 1 1}$ & Average & SD & CV \\
\hline IPDC & 12.39 & 11.58 & 9.91 & 11.26 & 11.29 & 1.033 & 0.092 \\
\hline IDLC & 12.63 & 10.44 & 10.07 & 12.33 & 11.37 & 1.299 & 0.114 \\
\hline ULCL & 12.3 & 11.97 & 10.92 & 12.88 & 12.02 & 0.823 & 0.068 \\
\hline PLCL & 14.14 & 11.9 & 11.28 & 13.25 & 12.64 & 1.293 & 0.102 \\
\hline ILFSL & 12.62 & 12.13 & 10.54 & 13.79 & 12.27 & 1.347 & 0.110 \\
\hline PFIL & 12.65 & 11.25 & 11.15 & 13.39 & 12.11 & 1.094 & 0.090 \\
\hline BAYLI & 12.38 & 10.02 & 11.55 & 14.88 & 12.21 & 2.032 & 0.166 \\
\hline PLFSL & 11.88 & 9.95 & 9.75 & 14.86 & 11.61 & 2.370 & 0.204 \\
\hline FLIL & 14.00 & 13.00 & 10.03 & 12.60 & 12.41 & 1.691 & 0.136 \\
\hline LBFL & 13.83 & 11.58 & 11.28 & 13.98 & 12.67 & 1.435 & 0.113 \\
\hline BIFC & 13.43 & 12.64 & 11.46 & 14.13 & 12.92 & 1.145 & 0.089 \\
\hline UCL & 13.05 & 11.96 & 11.99 & 15.20 & 13.05 & 1.520 & 0.117 \\
\hline NHFI & 13.45 & 10.49 & 10.2 & 12.42 & 11.64 & 1.558 & 0.134 \\
\hline IIDFCL & 14.1 & 14.11 & 12.91 & 13.71 & 13.71 & 0.563 & 0.041 \\
\hline FIASCL & 13.44 & 13.28 & 13.62 & 17.18 & 14.38 & 1.872 & 0.130 \\
\hline PLIL & 13.89 & 12.23 & 12.56 & 13.65 & 13.08 & 0.811 & 0.062 \\
\hline Average & $\mathbf{1 3 . 1 4}$ & $\mathbf{1 1 . 7 8}$ & $\mathbf{1 1 . 2 0}$ & $\mathbf{1 3 . 7 2}$ & $\mathbf{1 2 . 4 6}$ & $\mathbf{1 . 1 6 7}$ & $\mathbf{0 . 0 9 4}$ \\
\hline SD & $\mathbf{0 . 7 3 9}$ & $\mathbf{1 . 1 7 1}$ & $\mathbf{1 . 1 3 7}$ & $\mathbf{1 . 3 9 1}$ & $\mathbf{0 . 8 4 3}$ & & \\
\hline CV & $\mathbf{0 . 0 5 6}$ & $\mathbf{0 . 0 9 9}$ & $\mathbf{0 . 1 0 1}$ & $\mathbf{0 . 1 0 1}$ & $\mathbf{0 . 0 6 8}$ & & \\
\hline
\end{tabular}

Source: Authors' own calculation, Data: Annual Report of respective NBFI

$$
--0--
$$

